\title{
PAMALI DALAM KEHIDUPAN MASYARAKAT KECAMATAN CIGUGUR KABUPATEN KUNINGAN (Kajian Semiotik dan Etnopedagogi)
}

\author{
Hesti Widiastuti \\ Pos-el: hestiwidi2009@gmail.com
}

\begin{abstract}
Abstrak
Penelitian ini dilatarbelakangi oleh kurangnya pengetahuan masyarakat Kecamatan Cigugur Kabupatén Kuningan tentang Pamali. Penelitian ini bertujuan untuk mengumpulkan pamali yang masih ada di masayarakat Kecamatan Cigugur Kabupatén Kuningan, mengklasifikasi pamali yang ditemukan, memberi interpretasi melalui teori semiotik, dan mengungkap nilai moral yang ada dalam pamali memalui teori etnopedagogi. Metode yang dipakai dalam penelitian ini adalah metode Kualitatif dengan metode deskriptif. Sumber data dalam penelitian ini adalah pamali yang hidup di masyarakat Kecamatan Cigugur Kabupatén Kuningan yang terdiri dari sepuluh desa. Teknik yang dipakai dalam penelitian ini adalah teknik wawancara dan teknik observasi langsung. Berdasarkan hasil penelitian, didapat 188 pamali yang terkumpul dari sepuh desa. Berdasarkan klasifikasinya pamali terbagi menjadi enam klasifikasi diantaranya (1) ada 30 pamali untuk wanita hamil, (2) 14 pamali untuk anakanak, (3) 79 pamali untuk kebiasaan sehari-hari, (4) 24 pamali untuk waktu, (5) 13 pamali untuk lelaki dan perempuan, terakhir (6) 28 pamali husus. Berdasarkan unsur semiotik pamali terbagi jadi tiga unsur yaitu 31 pamali termasuk unsur Ikon, 60 pamali termasuk unsur Indeks, dan 97 pamali termasuk unsur Simbol. Sedangkan hasil analisis pamali berdasarkan unsur etnopedagogi terbagi dalam beberapa unsur yaitu 13 pamali termasuk ke dalam unsur etnopedagogi silih asih, ada 16 pamali yang termasuk ke dalam unsur etnopedagogi silih asuh, ada 10 pamali yang termasuk unsur etnopedagogi pengkuh agama, ada 13 pamali termasuk unsur etnopedagogi luhung élmuna, ada 44 pamali yang termasuk ke dalam unsur etnopedagogi jembar budayana, ada sembilan pamali yang termasuk unsur etnopedagogi rancagé gawéna, ada 43 pamali yang termasuk ke dalam unsur cageur, ada 32 pamali yang termasuk unsur etnopedagogi bener, ada lima pamali yang termasuk ke dalam unsur etnopedagogi singer, ada enam unsur etnopedagogi moral manusia kepada Tuhan, ada 45 pamali termasuk dalam unsur etnopedagogi moral manusa kepada pribadi, ada 24 pamali yang termasuk ke dalam unsur etnopedagogi moral manusia ke manusia lain, ada Sembilan pamali yang termasuk pada unsur etnopedagogi moral manusia kepada alam, dan terakhir ada 18 pamali yang termasuk pada unsur etnopedagogi moral manusia kepada tujuan hidupnya.
\end{abstract}

Kata Kunci: Pamali di Kecamatan Cigugur, Semiotik, Etnopedagogi.

\section{PAMALI IN THE LIFE OF THE PEOPLE OF CIGUGUR-KUNINGAN (The Study of Structure and Ethnopedagogy)}

\begin{abstract}
This research is motivated by the lack of knowledge about pamali (lit. taboo) among the People of Cigugur District, Kuningan Regency. This study aimed to collect the taboos that still exist in the People of Cigugur, to classify the pamalis found, to give interpretation through semiotic theory, and to reveal the moral values that exist through ethnopedagogy theory. The method used in this research was qualitative descriptive method. The data source in this study was the pamali exist the People of Cigugur District, Kuningan Regency -
\end{abstract}


consisting of ten villages. The techniques used in this research were interview and direct observation. Based on the research results, there are 188 pamalis collected from the elderly of the villages. They were classified into six classifications: (1) 30 pamalis for pregnant women; (2) 14 pamalis for children; (3) 79 pamalis in daily habits; (4) 24 pamalis in time, (5) 13 pamalis for men and women, and (6) 28 specific pamalis. , Based on their semiotic elements, pemalis were divided into three elements. They are 31 icons, 60 Index, and 97 symbols. Meanwhile, based on their ethnopedagogical elements, the pamalis were divided into: 13 silih asih, 16 silih asuh, 10 pengkuh agama, 13 pengkuh élmuna, 44 jembar budayana, 9 rancage gawéna, 43 cageur, 32 bener, 5 singer, 6 human moral toward God, 45 human moral toward personal, 24 human moral toward fellow-human, 9 human moral toward nature, and 18 human moral toward purpose of life.

Keywords: Pamali in Cigugur District, Semiotik, Etnopedagogi

\section{PENDAHULUAN}

Budaya merupakan hasil dari pemikiran manusia. Budaya timbul dari cipta rasa dan karsa manusia yang dijadikan kebiasaan dalam kehidupannya. Manusia sebagai makhluk sosial tentunya tidak akan pernah bisa hidup sendiri, dalam kehidupan sosialnya budaya hidup mempengaruhi cara manusia bersosialisasi. Hal ini diungkapkan oleh seorang ahli William A. Haviland dalam Sundjaya (2008, hal. 4) yang menyebutkan masyarakat adalah sekelompok manusia yang mendiami suatu daerah dan mempunyai kebudayaan yang sama. Artinya sebuah masyarakat baru bisa disebut sebuat masyakarat jika mempunyai kebudayaan dan pola hidup yang sama.

Kebudayaan merupakan sebuah sistem yang diciptakan oleh masyarakat untuk kelangsungan masyarakat itu pula. Menurut Koentjaraningrat (2009, hal. 144) ada tujuh unsur budaya yang hidup di dalam sistem masyarakat yaitu (1) Sistem kepercayaan, (2) Ilmu pengetahuan, (3) Sistem sosialo dan organisasi kemasyarakatan, (4) bahasa, (5) kesenian, (6) sistem pekerjaan, dan (7) sistem teknologi.

Dari kebudayaan-kebudayaan yang hidup dalam masyarakat dalam jangka waktu yang lama, masyarakat membentuk pola-pola dari unsur-unsur kebudayaan di atas. Salasatu produk budayanya yaitu Folklor. Folklor adalah bagian dari budaya yang bersifat lisan. Folklor terbagi menjadi tiga yaitu folklor lisan, folklor setengah lisan dan folklor non-lisan. Folklor yang bersifat lisan sangat erat dengan kebudayaan yang hidup di dalam suku Sunda, hal ini dikarenakan tradisi lisan yang hidup lebih dulu dari tradisi tulis di dalam perkembangan budaya tanah Sunda. budaya masyarakatnya terhadap tradisi lisan terbukti dengan adanya karya-karya peninggalan sejarah yang cenderum lisan seperti pupuh, carita pantun, pamali, dongeng, wawacan, dan lain sebagainya.

Dalam penelitian ini penulis meneliti salahsatu produk budaya yaitu pamali. Pamali merupakan salasatu produk folklor setengah lisan dalam bentuk kepercayaan masayarakat. Pamali adalah sering dianggap tabu oleh sebagian masyarakatnya, sering pula masyarakat menganggap pamali sebagai mitos atau sebatas warisan leluhur. Menurut Danadibrata (2009, hal. 489) dalam kamusnya menyebutkan pamali adalah sebagai suatu larangan yang jika dilarang akan mendatangkan celaka. Dalam beberapa pembahasan pamali juga berperan sebagai aturan-aturan masyarakatnya hususnya masyarakat Sunda yang mengatur segala pola hidup masyarakatnya diluar kepercayaan masyarakat terhadap agama. Pamali belum bisa ditentukan berasal dari mana bahkan sejak kapan, yang jelas pamali banyak dimiliki oleh suku bangsa di Indonesia. Husus untuk masyarakat Sunda, pamali menjadi sebuah aturan yang sangat tabu sehingga masyarakatnya memegang 
teguh aturan yang ada dalam pamali tersebut.

Dalam penelitian ini penulis menjadikan Kecamatan Cigugur Kabupaten Kuningan sebagai sumber data, data yang dihasilkan adalah pamali yang hidup di masyakata Kecamatan Cigugur Kabupaten Kuningan. Penulis memilih Kecamatan Cigugur sebagai objek penelitian dikarenakan pola hidup masyarakatnya yang masih memegang teguh pamali sehingga pamali masih dipakai dalam kehidupanya sehari-hari. Apalagi di jaman yang sudah modern ini, sudah tentu banyak perubahan-perunbahan yang terjadi pada pola hidup masyarakatnya. Rasa penasaran penulis terhadap pamali yang hidup di masayarakat Kecamatan Cgugur di jaman modern ini yang membuat penulis mengadakan penelitian ini. Penelitian ini bertujuan untuk mengumplkan pamali yang masih dipakai oleh masyarakat Kecamatan Cigugur, memberi klasifikasi pada pamali yang ada, menginterpretasi pamali yang hidup di masyarakat, dan menganalisis nilai pendidikan dari pamali tersebut.

Pamali sering dianggap hanya mitos dan tabu leluhur semata, tapi penulis mengaggap pamali mempunyai tujuan dan fungsi yang penting di masayarakat. Selain itu penulis ingin menggali makna sebenarnya dari pamali tersebut. Untuik itu penelitian ini dianggap penting untuk dilaksanakan.

Dalam penelitian ini teori yang dipakai untuk menganalisis pamali diantaranya teori semiotik dan etnopedagogi. Semiotik adalah ilmu tanda, dimana smua kehidpan mempunyai tanda yang mempunyai makna. Perkembangan semiotik dalam sejarahnya didominasi oleh dua ahli yaitu Ferdinan de Sausure jeung Charles Sanders Peirce. Sausure sebagai ahli linguistik memandang semiotik sebagai ilmu tanda yang dikupas melalui bahasa. Sedangkan Peirce sebahai ahli filsafat lebih luas memandang semiotik sebagai ilmu tanda. Peirce menghubungkan tanda yang ada dengan cabang ilmu lainnya untuk mendapatkan makna yang paling benar. Semiotik Peirce bersifat analitik, dan mengartikan semiotik sebagai logika. Peirce juga membagi tiga bagian dalam semiotik yang sering disebut trikonomi tanda. Trikonomi tanda pertama membahas hubungan objek dengan tanda, trikotomi kedua membahas hubungan representamen dan tanda dan yang ketiga trikotomi ketiga membahas hubungan interprener dan tanda. Pada penelitian ini penulis mengupas trikonomi tanda yang pertama yaitu hubungan objek dengan tanda. Dalam hungan objek dengan tanda ini dibagi lagi menjadi tiga bagian yaitu ikon, indeks dan simbol.

Sedangkan teori yang kedua adalah teori etnopedagogi. Etnopedagogi adalah ilmu yang berbasis pada kearifan lokal. Menurut Alwasilah (2009, hal. 50) etnopedagogi adalah praktek pendidikan yang berdasar dari kearifan lokal. Artinya bahan pengajaran didasarkan pada kearifan lokal setempat. Tujuan etnopedagogi adalah untuk mewariskan nilai-nilai budaya yang hidup serta bisa memaknai warisan leluhur bukan hanya sekedar sebagai peninggalan sejarah tapi juga sebagai nilai pendidikan. Dalam etnopedagogi dibutuhkan cabang ilmu lainnya untuk menggali lebih dalah suatu objek.

Dalam penelitian ini nilai etnopedagogi yang diambil ada empat nilai karakter yang disampaikan Suryalaga (2010, kc. 17) yaitu (1) Prilaku Nyunda Trisilas; (2) Catur Jatidiri Insan; (3) Panca Rawayan (Gapura Panca Waluya); dan (4) Moral Kemanusiaan. Prilaku nyunda trisilas terdiri dari sipat silih asih, silih asuh dan silih asah. Artinya saling menyayangi, saling menjaga dan saling berbagi ilmu. Dalam karakter ini nilai yang ingin disampaikan bahwa manusia sebagai makhluk sosial tidak mungkin bisa hidup sendiri untuk itu harus saling menghargai satu sama lainnya agar tercipta hidup yang damai.

Nilai pendidikan yang kedua adalah catur jatidiri insan. Dalam nilai yang kedua ini dibagi menjadi empat karakter yaitu 
pengkuh agamana, luhung élmuna, jembar budayana, dan rancagé gawéna. Pengkuh agama maksudnya adalah memegang kuat aturan agama yang dianutnya, luhung elmuna artinya pengetahuannya luas, jembar budayana mengandung arti menghargai akan budaya yang hidup disekelilingnya dan juga tidak gagap budaya, yang terakhir rancagé gawéna maksudnya gigih dalam bekerja.

Selanjutnya Panca Rawayan (Gapura Panca Waluya) ini terdiri dari lima sipat yang identik dengan orang Sunda yaitu cageur, bageur, bener, pinter, dan singer. Cageur artinya sehat jasmani dan rohani, bageur artinya mempunyai sipat yang baik hati dan saling menghormati, bener artinya menjalani hidup sesuai ketentuan yang sudah ada seperti jujur, adil dan lain-lain, pinter artinya pintar dalam menyikapi semua permasalahan hidup, dan singer artinya kreatif dan penuh inovasi.

Dan yang terakhir adalah moral kemanusiaan. Ada enam moral kemanusiaan yang meliputi moral manusia terhadap Tuhan, moral manusia terhadap pribadi, moral manusia terhadap sesama, moral manusia terhadap waktu, dan moral manusia terhadap tujuan hidupnya. Semua moral kemanusiaan yang ada mencangkup semua aspek yang ada dalam kehisupan manusia.

\section{METODE}

Sumber data dalam penelitian ini menitikberatkan kepada masyarakat yang hidup di daerah Kecamatan Cigugur Kabupaten Kuningan. ada sepuluh desa yang ada di Kecamatan Cigugur diantaranya desa Puncak, desa Babakanmulya, desa Cileuleuy, desa Cigugur, desa Sukamulya, desa Cigadung, desa Cisantana, desa Gunungkeling, desa Cipari, dan desa Winduherang.

Kriteria narasumber dalam penelitian ini adalah lalaki atau perempuan dengan minimal usia 50 tahun, serta memiliki pengetahuan tentang pamali, dan tidak pernah menempati daerah lain lebih dari satu tahun. Setelah mendapatkan keterangan yang ada, narasumber dalam penelitian ini beragama mulai dari petani, sesepuh desa, paraji, dan pensiunan.

Penelitian ini menggunakan metode kualitatif dengan analisis deskriptif. Metode kualitatif ini digunakan untuk menganalisis objek yang yang tidak bisa diukur menggunakan angka. Pamali merupakan objek yang non eksak, artinya hanya bisa didekskripsikan menggunakan kata-kata.

Metode kualitatif digunakan dalam penelitian ini dilatarbelakangi oleh sipat metode kualitatif. Ada lima metode kualitatif yaitu (1) bersifat induktif, maksudnya mempunyai dasar logika yang jelas, (2) memahami pola hidup manusia berdasarkan sudut pandang penulis, sehingga penulis mampu mendeskripsikan hasil penelitian secara jelas, (3) lebih mementingkan proses penelitian dari pada hasil penelitian, (4) sipatnya humanistis, dan (5) segala aspek kehidupan yang ada di masyarakat dianggap penting. Berdasarkan sipat metode kualitatif tersebut penulis mampu mencapai tujuan penelitian yang ingin menginterpretasi dan mengungkap makna pamali yang ada.

Penelitian yang menggunakan analisis deskriptif tidak bisa lepas dari metode kualitatif yang dianggap efektif untuk menemukan fakta atas data penelitian. Hal ini disampaikan oleh Suyanto dan Sutinah (2006, hal. 80) dalam empat langkat penelitian kualitatif. Empat langkah yang dimaksud adalah (1) mengumpulkan data, (2) menganalisis data, (3) menapsirkan data, dan (4) membuat kesimpulan.

Berdasarkan langkah-langkah diatas, pada point menafsirkan data dalam penelitian ini menggunakan analisis semiotik dan etnopedagogi. Unsur semiotik yang digali adalah ikon, indeks dan simbol, sedangkan unsur etnopedagogi nya terdiri dari perilaku Nyunda Tri - Silas, Catur Jatidiri Insan, Pancarawayan (Gapura Panca Waluya), jeung Moral kemanusiaan.

Dalam pengambilan data, dalampenelitian ini menggunakan teknik 
wawancara dan observasi langsung dengan narasumber. Instrumen yang digunakan berupa handycam, kamera, pedoman wawancara dan kartu data.

\section{HASIL DAN PEMBAHASAN}

Dari hasil penelitian langsung kepada masyarakat Kecamatan Cigugur Kabupaten Kuningan yang terdiri dari sepuluh desa diantaranya desa Puncak, desa Babakanmulya, desa Cileuleuy, desa Cigugur, desa Sukamulya, desa Cigadung, desa Cisantana, desa Gunungkeling, desa Cipari, dan desa Winduherang.

Di desa Puncak ada nya eta 97 pamali, di desa Babakanmulya ada 78 pamali, di desa Cileuleuy ada 94 pamali, di desa Sukamulya ada 109 pamali, di desa Cigadung ada 98 pamali, di desa Cigugur ada 84 pamali, di desa Cisantana ada 99 pamali, di desa Gunungkeling ada 88 pamali, di desa Cipari ada 115 pamali, dan di desa Winduherang ada 97 pamali. Setelah dianalisisdidapat 188 pamali yang berbeda yang terdapat di sepuh desa tersebut. Dari 188 pamali yang ada, dibagi menjadi enam klasifikasi pamali sesuai jenis pamalinya. Diantaranya ada 160 pamali yang berasal dari sepuh desa dan 28 pamali yang terdiri dari Sembilan desa. Enam klasifikasi pamali tersebut terdiri dari pamali untuk ibu hamil, pamali untuk anakanak, pamali untuk kegiatan sehari-hari, pamali untuk waktu, pamali untuk lelaki dan perempuan, dan pamali husus.

Pamali yang ditujukan bagi ibu hamil adalah pamali yang brkaitan dengan larangan bagi wanita yang sedang hamil, baik itu hamil muda ataupun sudah mengijak bulan ke Sembilan. Sedangkan pamali bagi anak-anak ditujukan kepada anak-anak yang disaran usia 0-10 tahun. Pamali selanjutnya pamali untuk kegiatan sehari-hari maksudnya untuk kegiatan yang biasa dikerjakan sehari-hari yang menjadi rutinitas seperti makan, minum, berjalan, melakukan pekerjaan rumah dan lainnya. Pamali yang ditujukan kepada waktu maksudnya pamali yang ditujukan pada waktu yang sedang berjalan, yang sudah berjalan dan yang akan berjalan. Selanjutnya pamali untuk laki-laki dan perempuan yaitu pamali yang ditujukan kepada pemuda yang belum menikah ataupun sudah menikah dan perempuan yang belum menikah atau perawan. Dan terakhir pamali husus ditujan bagi pamali yang hidup hanya di desa tertentu dan aturan pamalipun hanya berpengaruh di daerah tertentu saja.

Berdasarkan penjelasan diatas ada 30 pamali yang ditujukan bagi ibu hamil, 14 pamali untuk anak-anak, 77 pamali untuk kegiatan sehari-hari, 24 pamali yang ditujukan kepada pengaturan waktu, 15 pamali yang ditujukan bagi lalaki dan perempuan, dan 28 pamali yang ditujukan husus untuk desa tertentu.

Setelah dianalis menggunakan analisis semiotik didapat hasil dari 188 pamali yang ada 31 pamali termasuk kedalam ikon, 60 pamali termasuk indeks dan 97 pamali termasuk kedalam simbol. Sedangkan hasil analisis etnopedagogi didapat 13 pamali yang mempunya nilai silis asih, 16 pamali mengandung nilai silih asuh, terus ada 10 pamali yang termasuk pada nilai pengkuh agama, 13 pamali mengandung unsur luhung elmu, 44 nilai jembar budaya dan ada sembilan pamali yang mengandung nilai rancagé gawéna. Selanjutnya ada 32 pamali yang mempunyai nilai bener, lima pamali mengandung nilai singer, ada enam pamali yang mengandung nilai moral manusia kepada Tuhan, 45 pamali yang mengandung nilai moral manusia kepada pribadi, serta ada 24 pamali yang mengandung nilai moral manusia kepada sesama, ada sembilan pamali yang mempunyai nilai moral manusia kepada alam, dan terakhir ada 18 pamali yang mengandung nilai moral manusia kepada tujuan hidupnya.

Pamali sebagai salahsatu unsur kebudayaan mempunya semua unsur yang dikemukakan oleh Koentjaraningrat (2009, hal. 165) yaitu (1) sistem religi, (2) sistem ilmu pengetahuan,(3) sistem sosial dan 
organisasi kemasyarakatan, (4) sistem bahasa, (5) kesenian, (6) sistem pekerjaan, dan (7) sistem teknologi.

Selain dari ketujuh unsur kebudayaan tersebut, pamali juga mempunyai nilai-nilai etnopedagogi yang tersembunyi dalam makna-makna pamali yang ada. Dalam setiap sistem kebudayaan yang hidup tentunya berkaitan pula dengan nilai-nilai moral ataupun pendidikan di dalamnya, untuk itu unsur kebudayaan dan etnopedagogi saling berkaitan dan berhubungan. Dalam penelitian ini keterkaitan antara unsur kebudayyaan dan unsur etnopedagogi digambarkan dalam bentuk pamali yang mempunyai nilai etnopedagogi seperti yang disampaikan di dalam hasil penelitian diatas. Selain unsur etnopedagogi terdapat pula unsur semiotik yang tersembunyi dalam pamali, misalnya ada pamali yang merupakan ikon, indeks maupun simbol yang dapat menggali makna dari pamali tersebut.

Dari 188 pamali yang ada di masyarakat Kecamatan Cigugur Kabupaten Kuningan ada beberapa pamali yang mengandung unsur kebudayaan sistem religi seperti ulah liar ti magrib bisi dirawu kalong. Arti pamali tersebut adalah jangan berkeliaran di waktu magrib, takut diambil setan, dalam pamali ini didapat beberapa unsur etnopedagogi seperti pengkuh agamnana dan moral manusia kepada Tuhannya. Ada delapan pamali yang melibatkan kata "Magrib" ini menunjukan adanya ketaatan masyarakat dalam menjalan perintah agamanya yaitu shalat Magrib. Selain itu yang berhubungan dengan sistem religi ada pamali ulah miara anjing gigireun imah, bisi malaikat hésé asup ka imah, artinya jangan memelihara anjing di pinggir rumah takut malaikat tidak bisa masuk ke dalam rumah. Anjing dalam hal ini adalah hewan yang diharamkan oleh umat muslim, sehingga jiga memeliharanya akan berdosa karena anjing mengandung najis yang dapat merusak ibadah umat muslim. Hal ini jelas berkaitan dengan nilai-nilai ketuhanan yang ada dalam etnopedagogi sendiri. Jika dilihat dari unsur semiotiknya, kedua pamali tersebut termasuk ke dalam simbol. Hal ini dikarnakan kata "magrib" jadi simbol menjelang malam, dan malam diidentikan dengan keluarnya para setan. Selanjutnya kata "anjing" menjadi simbol hewan yang diharamkan dalam kepercayaan masyarakat muslim.

Pada unsur kebudayaan kedua yaitu sistem ilmu pengetahuan. Dalam pamali juga terdapat unsur yang berkaitan dengan ilmu pengetahuan, sama halnya dengan etnopedagogi. Dalam etnopedagogi ada unsur pinter yang berarti pintar dalam menyelesaikan masalah, dan ada luhung élmuna yang artinya mempunyai wawasan yang luas. Ada 13 pamali yang mempunyai nilai luhung elmuna, sebagai contoh ada pamali ulah dahar bari nangtung artinya jangan makan sambil berdiri, kemudian ada pamali ulah diuk dina bantal artinya jangan duduk di atas bantal, dan ulah make baju bari leumpang artinya jangan memakai baju sambil berjalan. Ketiga pamali tersebut memberi larangan terhadap apa yang tak sepantasnya dikerjakan. Artinya masyarakat sudah mempunyai pengetahuan yang cukup luas dalam menjalankan etika dalam kehidupannya, secara kesehatan makan sambil berdiri itu tidak bagus karena akan mengganggu sistem pencernaan, duduk diatas bantal dilarang karena bantal digunakan untuk kepala artinya tidak sopan, dan memakai baju sambil berjalan tidak pantas karena bisa menyebabkan kita jatuh atau lainnya. Kaitannya dengan unsur semiotik, ketiga pamali tersebut termasuk kedalam indeks. Hal ini dikarenakan kalimat makan sambil berjalan bisa menjadi indikasi adanya gangguan pencernaan pada perut, dan memakai baju sambil berjalan bisa jadi indikasi celaka karena tidak melihat jalan dengan baik.

Unsur kebudayaan yang ketiga yaitu sistem sosial dan organisasi kemasyarakatan. Dalam unsur ini jika dikaitkan dengan unsur etnopedagogi dan semiotik, yang berkaitan dengan unsur 
etnopedagoginya adalah nilai silih asih, silih asuh jeung silih asah maksudnya saling menyayangi menghargai dan mengajari. Ada beberapa pamali yang mempunyai makna yang berkaitan diantaranya ulah nyeungseurikeun hitut bisi ompong artinya jangan mentertawakan orang yang kentut karena takut ompong. Makna jangan mentertawakan dalam konteks ini adalah harus saling menghargai dan menyayangi tidak boleh mengejek orang lain dengan cara mentertawakan. Dikaitkan dengan ompong adalah hukuman jika mentertawakan maka giginya bisa hilang dan akan malu sendiri. Dari penjelasan tersebut dapat terlihat nilai moral saling menghargai dan menyayangi sangat jelas dalam pamali ini. Jika dikaitkan dengan semiotik pamali ini termasuk kedalam simbol

Selanjutnya unsur yang keempat yaitu sistem bahasa. Dalam penggunaan bahasa tentu saja dalam pamali mempunya keterkaitan yang sangkat erat karena pamali adalah salahsatu sistem bahasa yaitu bahasa sunda yang diungkapkan masyarakat secara lisan. Pamali yang husus membahas bahasa misalnya ada pamali ulah nyebut embé kudu uncal kalong, bisi aya jurig. Artinya jiga menyebut kambing harus uncal kalong. Ini membuktikan adanya aturan bahasa yang digunakan masyarakat dalam pamali. secara semiotik unsur yang didapat dari pamali tersebut adalah simbol karena ini menyimbolkan larangan yang berkaitan dengan sejarah dan dongeng yang berkembang di daerah tersebut.

Unsur kebudayaan yang kelima adalah kesenian. Seandainya dihubungkan dengan unsur etnopedagogi ada unsur yang berkaitan dengan hal tersebut yaitu jembar budayana. Kesenian termasuk dalam kebudayaan yang hidup di masyarakat, ada beberapa pamali yang menunjukan hal tersebut sebagai contoh nanggap wayang, bisi malarat artinya jangan mementaskan kesenian wayang takut jatuh miskin. Kesenian wayang adalah kesenian yang berasal dari Jawa, husus di daerah sunda biasanya wayang golek yang jadi pertunjukannya. Adanya larangan masyarakat Cigugur terhadap kesenian ini dilatar belakangi oleh cerita dan sejarah di daerahnya. Jika dikaitkan dengan semiotik pamali ini mengandung unsur ikon karena pementasan wayang dikenal sangat mahal jadi jika ingin menyewa pertunjukannya harus mengeluarkan banyak uang.

Unsur yang keenam adalah sistem pekerjaan. Masyarakat Cigugur yang cenderum mempunyai latar belakang petani mempunyai banyak larangan bagi para petani dalam mengeloloa sawahnya. Jika dihubungkan dengan etnopedagogi ada beberapa unsur yang berkaitan seperti rancagé gawé yang berarti gigih dalam bekerja dan singer artinya kreatif dan inovatif. Pamali yang mempunya unsur ini diantaranya ulah ka sawah tengah poé yang artinya jangan pergi ke sawah di siang hari, dan ulah ngarit tengah poé artinya jangan menyabit di siang hari. Kedua pamali ini menunjukan adanya larangan bagi para petani untuk melakukan pekerjaannya diwaktu istirahat.

Unsur sistem teknologi. Jika dihubungkan dengan unsur etnopedagogi ada beberapa nilai diantaranya moral manusia kepada alam, hal ini berkaitan dengan teknologi masyarakatnya dalam menjaga alam. Ada beberapa pamali yang berkaitan diantaranya ulah ngala peuteuy dina poé manis artinya jangan memetik petay di hari manis (dalam itungan masyarakat Sunda), terus ada pamali ulah nuar awi dina poé manis, wage, jeung kaliwon artinya jangan menebang bambu di hari manis, wage, dan kliwon (itungan dalam masyarakat Sunda). Kaitannya dengan sistem teknologi dalam unsur kebudayaan adalah masyarakatnya telah mempunyai itungan kalendernya sendiri untuk menentukan musim. Cara menjaga alam melalui pamali ini dijelaskan dalam larangannya jangan menebang bambu dalam seminggu tiga kali banyaknya. Ini hal jelas dipeuntukan untuk kelangsungan hidup alam di hutan, jika bambu ditebang 
tiga kali dalam seminggu bisa jadi hutan akan rudak dan akan terjadi bencana alam. Jika dikaitkan dengan unsur semiotik, pamali ini berkaitan dengan unsur simbol.

\section{SIMPULAN}

Kesimpulannya dari sepuh desa yang ada di Kecamatan Cigugur Kabupaten Kuningan terdapat 97 pamali di desa Puncak, di desa Babakanmulya ada 78 pamali, di desa Cileuleuy ada 94 pamali, di desa Sukamulya ada 109 pamali, di desa Cigadung ada 98 pamali, di desa Cigugur ada 84 pamali, di desa Cisantana ada 99 pamali, di desa Gunungkeling ada 88 pamali, di desa Cipari ada 115 pamali, dan di desa Winduherang ada 97 pamali. Sabada ditalungtik aya pamali anu sarua dipake disababaraha desa, ku kituna aya 188 pamali anu hirup di sapuh desa di Kecamatan Cigugur Kabupaten Kuningan. Berdasarkan hasil penelitian tersebut ada 188 pamali berbeda yang hidup di masyarakat Kecamatan Cigugur Kabupaten Kuningan.

Dari 188 pamali yang ada, dibagi menjadi enam klasifikasi pamali sesuai jenis pamalinya. Diantaranya ada 160 pamali yang berasal dari sepuh desa dan 28 pamali yang terdiri dari Sembilan desa. Enam klasifikasi pamali tersebut terdiri dari pamali untuk ibu hamil, pamali untuk anakanak, pamali untuk kegiatan sehari-hari, pamali untuk waktu, pamali untuk lelaki dan perempuan, dan pamali husus.

Berdasarkan penjelasan diatas ada 30 pamali yang ditujukan bagi ibu hamil, 14 pamali untuk anak-anak, 77 pamali untuk kegiatan sehari-hari, 24 pamali yang ditujukan kepada pengaturan waktu, 15 pamali yang ditujukan bagi lalaki dan perempuan, dan 28 pamali yang ditujukan husus untuk desa tertentu.

Setelah dianalis menggunakan analisis semiotik didapat hasil dari 188 pamali yang ada 31 pamali termasuk kedalam ikon, 60 pamali termasuk indeks dan 97 pamali termasuk kedalam simbol. Sedangkan hasil analisis etnopedagogi didapat 13 pamali yang mempunya nilai silis asih, 16 pamali mengandung nilai silih asuh, terus ada 10 pamali yang termasuk pada nilai pengkuh agama, 13 pamali mengandung unsur luhung elmu, 44 nilai jembar budaya dan ada sembilan pamali yang mengandung nilai rancagé gawéna. Selanjutnya ada 32 pamali yang mempunyai nilai bener, lima pamali mengandung nilai singer, ada enam pamali yang mengandung nilai moral manusia kepada Tuhan, 45 pamali yang mengandung nilai moral manusia kepada pribadi, serta ada 24 pamali yang mengandung nilai moral manusia kepada sesama, ada sembilan pamali yang mempunyai nilai moral manusia kepada alam, dan terakhir ada 18 pamali yang mengandung nilai moral manusia kepada tujuan hidupnya.

\section{PUSTAKA RUJUKAN}

Alwasilah, A.C, Spk., (2009) Etnopedagogi :Landasan Praktek Pendidikan dan Pendidikan Guru. Bandung: Kiblat Buku Utama.

Danadibrata. (2009). Kamus Basa Sunda. Bandung: Kiblat

Koentjaraningrat. (2009). Pengantar Ilmu Antropologi. Jakarta: PT. Rineka Cipta.

Sundjaya. (2008). Dinamika Kebudayaan. Jakarta: Nobel Edumedia.

Suryalaya, Hidayat. (2010). Filsafat Sunda. Bandung: Yayasan Nurhidayat.

Suyanto dan Sutinah. (2006). Metode Penelitian Sosial. Jakarta: Kencana.

Universitas Pendidikan Indonesia. (2014). Pedoman Penulisan Karya Ilmiah.

\section{UCAPAN TERIMA KASIH}

Terima kasih kepada pembimbing, penguji, dan teman sejawat yang telah membimbing dan memberi bantuan kepada penulis. Juga kepada jurnal Lokabasa yang telah menerbitkan artikel ini, penulis ucapkan terima kasih. 